\title{
Genetic structure and variability of phenological forms in the European beech (Fagus sylvatica L.)
}

\author{
${\text { Wojciech } \mathrm{KRAJ}^{1 *} \text {, Agnieszka SzTORC }}^{2}$ \\ ${ }^{1}$ Department of Forest Pathology, Agricultural University, Al. 29-Listopada 46, 31-425 Cracow, Poland \\ ${ }^{2}$ W. Szafer Institute of Botany, PAS, Lubicz 46, 31-512 Cracow, Poland
}

(Received 28 March 2008; accepted 25 November 2008)

Keywords:

beech /

variability /

microsatellites /

genetic structure /

phenological forms
Mots-clés :

hêtre /

variabilité /

microsatellites /

structure génétique /

formes phénologiques

\begin{abstract}
- Microsatellite markers were used to describe the genetic structure and variability of early, intermediate and late phenological forms of European beech (Fagus sylvatica L.). Two hundred and seventy individuals from three populations located in southern Poland were divided into three forms according to the phenological criterion - bud burst, and analyzed for allelic variation at five highly polymorphic microsatellite loci.

- Population differentiation was moderate and differed significantly among phenological forms. Average values of $F_{\mathrm{ST}}$ and $R_{\mathrm{ST}}$ decreased across phenological forms and amounted to $F_{\mathrm{ST}}$ values of $0.135,0.110$ and 0.108 and $R_{\mathrm{ST}}$ values of $0.365,0.231$ and 0.098 for early, intermediate and late forms of beech, respectively.

- Analysis of Molecular Variance (AMOVA) revealed different genetic structures characteristic of respective phenological forms of beech. The amount of within-population variability increased with the delay of the beginning of vegetation and amounted to $64 \%, 77 \%$ and $90 \%$ of total variability, depending on phenological form. A similar trend was found in average pairwise genetic distance between individuals belonging to a given phenological form $(11.78,11.85$ and 12.22 , from early to late forms).

- Our results demonstrate the importance of late spring frosts as a factor influencing the genetic structure of beech, and as a cause of the decrease in genetic variability as well as the increase in population differentiation proportional to the degree of phenological earliness.
\end{abstract}

Résumé - Structure génétique et variabilité des formes phénologiques du hêtre (Fagus sylvatica L.).

- Des marqueurs microsatellites ont été utilisés pour décrire la structure génétique et la variabilité des formes phénologiques précoces, intermédiaires et tardives du hêtre (Fagus sylvatica L.). Deux cent soixante-dix individus de trois populations situées dans le sud de la Pologne ont été répartis en trois groupes selon le critère phénologique de la précocité de débourrement, et analysés pour la variation allélique de cinq microsatellites à loci très polymorphes.

- La diversité intra-population était modérée et différait sensiblement entre les formes phénologiques. La moyenne des valeurs de $F_{\mathrm{ST}}$ et $R_{\mathrm{ST}}$ diminuait entre débourrement précoces et tardifs ; elle s'élevait à $0,135,0,110$ et 0,108 pour $F_{\mathrm{ST}}$ et des à $0,365,0,231$ et 0,098 pour $R_{\mathrm{ST}}$ pour les hêtres, respectivement précoces, intermédiaires et tardifs.

- L'analyse de la variance moléculaire (AMOVA) a révélé une structure génétique différente pour les différentes formes phénologiques de hêtre. L'importance de la variabilité intra population s'est accrue avec le retard du débourrement et s'est élevé à $64 \%, 77 \%$ et $90 \%$ de la variabilité totale, en fonction de la forme phénologique. Une tendance similaire a été trouvée, pour la distance génétique par paire moyenne, entre les individus appartenant à une même forme phénologique (11.78, 11.85 et 12.22, des formes précoces à tardives).

- Nos résultats montrent l'importance des gelées printanières en tant que facteur influant sur la structure génétique du hêtre et comme une cause de la diminution de la variabilité génétique, ainsi que l'augmentation de la différenciation de la population, proportionnelle au degré de précocité phénologique.

\footnotetext{
* Corresponding author: rlkraj@cyf-kr.edu.pl
} 


\section{INTRODUCTION}

The European beech (Fagus sylvatica L.) is one of the most important forest tree species occurring in Europe in terms of its role in the natural ecosystems of temperate regions, as well as its value for forestry and the economy. This species occupies various habitats ranging from mountainous regions of southern and eastern Europe to the lowlands of central Europe and southern Sweden (Fang and Lechowicz, 2006; Paule, 1995). The climate of these places decides the great variety of beech trees, which is mirrored by the genetic and morphophysiological features of the beech (Dolnicki and Kraj, 2001). Like other plants in temperate zones, European beech exists in conformity with the annual cycle of vegetation (Levins, 1969). After the dormancy period, new lives and flowers are produced in spring. The vegetation should start as early as possible to maximize photosynthetic production. It is also necessary that it starts at the correct time to protect young leaves against late spring frosts.

Climate conditions are key factors determining the distribution of plant species. The climate exerts selective pressure and has the potential to cause strong directional selection in natural populations including beech forests (Hedrick, 2000; Joshi et al. 2001; Jump and Peñuelas, 2007). Temperature plays the most important role as a selective factor of population differentiation (Fang and Lechowicz, 2006).

European beech is adapted to Atlantic and mountainous climates. It is also sensitive to climatic extremes such as drought and water deficit at lower altitudes, and extreme temperature and radiation conditions in stands located higher (Dittmar et al., 2003). The most negative environmental factor is late spring frosts, especially dangerous for seedlings and young specimens (Schieber, 2006; Visnjic and Dohrenbusch, 2004). They cause injuries or damage the assimilation apparatus, which result in death or limited growth of beech trees (Dittmar et al., 2006; Dolnicki and Kraj, 2001; Khristov and Botev, 1981). Late spring frosts also play a significant role in the degradation of tree shape, injuring or destroying terminal buds and increasing the incidence of forking (Ningre and Colin, 2007).

It is believed that variation in the date of the beginning of vegetation and the occurrence of early and late phenological forms is one of this species' defense strategies against the unfavorable impact of the environment, especially late frosts. The onset of the spring growth of beech buds varies both between populations across the geographical range and among individuals within particular populations. The differences between the bud-swelling date and the bud-breaking date of early and late beeches can be as much as 20 days (Chmura and Rozkowski, 2002; Dolnicki and Kraj, 2001). The date of bud breaking is an adaptive feature which remains under strong genetic control. It is stable across time but, just like other quantitative features, is also dependent on environmental factors (Frewen et al., 2000; Rambousek, 1994; Vernier et al., 1996). Like other quantitative features, the date of the beginning of vegetation is manifested in populations with a frequency which depends on the interaction of genotypes and environmental conditions (Howe et al., 2003; Schieber, 2006).
Therefore, specimens with different bud-breaking dates may coexist within the same stands. These phenotypes have different physiological and morphological features, such as their dynamic of frost resistance and of dormancy-breaking time at the end of winter, as well as the leaf size (Dolnicki and Kraj, 2001).

There are groups of specimens (populations, ecotypes and species) with different resistance levels to a given selective factor. The working hypothesis in our research was that the environmental pressure on early and late forms is enhanced with changes in the frequency of alleles, which lead to different shaping of the genetic variation of these groups of specimens. The objective of our research was to determine and compare within- and among-population variability and the genetic structure of phenological forms of beech.

\section{MATERIALS AND METHODS}

\subsection{Plant material and sampling method}

The investigation was conducted in three, 15- to 20-year-old beech populations resulting from natural regeneration and located in southern Poland: (i) the Forest Experimental Station in Krynica, Jaworzyna Forest District, 52k Forest Compartment, coordinates: $49^{\circ} 41^{\prime} \mathrm{N}, 20^{\circ}$ 95' E (Pop. 1); (ii) Kopce Forest District, 198j Forest Compartment, coordinates: $50^{\circ} 12^{\prime} \mathrm{N}, 19^{\circ} 66^{\prime} \mathrm{E}$ (Pop. 2); (iii) Ukleina Forest District, 142a Forest Compartment, coordinates: $49^{\circ} 83^{\prime} \mathrm{N}, 19^{\circ} 94^{\prime} \mathrm{E}$ (Pop. 3).

In May 2004, randomly selected trees were evaluated with respect to their phenological development. The phenological phases were estimated using the Teissier du Cross (1981) scale of European beech spring development, which distinguishes the following phases: 1st dormant buds; 2nd swollen and elongated buds; 3rd bursting buds, first revegetation; 4th appearance of plicate and hairy leaves; 5th single plicate and hair leaves; 6th leaves no longer plicate but still in the fan form, with hulls; 7th leaves no longer plicate but smooth and shiny. For the purpose of our analysis, the following three phenological forms of individuals were distinguished: (i) early form: individuals in the 6th or 7th developmental phase; (ii) intermediate form: individuals in the 4th or 5th developmental phase; (iii) late form: individuals in the 1st, 2nd or 3rd developmental phase.

In each of the three populations 30 individuals belonging to each of the three phenological forms (ecological subpopulations) were chosen, amounting to 90 samples per population. In total, 270 trees were taken into consideration. Trees belonging to respective classes were permanently marked in the field for subsequent sampling. In all studied populations, phenological observations and tree marking were performed on a day when distinct differences between trees were apparent. The sampling of plant material from all of the marked individuals was performed after the development of tree foliage was complete (about the 15th of June). Undamaged leaves were collected from terminal parts of branches and stored at $-80^{\circ} \mathrm{C}$.

\subsection{DNA isolation and microsatellite analysis}

The extraction of DNA from the leaves was performed using the CTAB method according to Carlson et al. (1991). DNA concentration and purity were determined spectrophotometrically. Five highly 
variable microsatellites previously isolated from $F$. sylvatica (FS1-15, FS1-25, FS1-03, FS1-11 and FS4-46) (Pastorelli et al., 2003) were amplified in a PCR reaction. The amplification was performed in $10 \mu \mathrm{L}$ of reaction mixture consisting of: $1 \times$ Taq Buffer (Fermentas), $\mathrm{MgCl}_{2}$ in concentrations dependent on the microsatellites $(2.5 \mathrm{mM}$ for FS1-15 and FS1-11; $2.0 \mathrm{mM}$ for FS1-25 and FS1-03; $1.5 \mathrm{mM}$ for FS4-46), $0.4 \mu \mathrm{M}$ each of primers (Proligo) and 1.2 U of Taq DNA polymerase (Fermentas). The thermal amplification profile was as follows: $5 \mathrm{~min}$ of initial denaturation at $95^{\circ} \mathrm{C}$, followed by $31 \mathrm{cy}$ cles of 1 min denaturation at $95^{\circ} \mathrm{C}, 1 \mathrm{~min}$ annealing at a temperature dependent on the microsatellites $\left(58{ }^{\circ} \mathrm{C}\right.$ for FS1-03; $60{ }^{\circ} \mathrm{C}$ for FS115 and FS4-46; $63{ }^{\circ} \mathrm{C}$ for FS1-11 and FS1-25) and 1 min extension at $72{ }^{\circ} \mathrm{C}$, followed by a final extension step at $72{ }^{\circ} \mathrm{C}$ for $8 \mathrm{~min}$. PCR was performed using a Biometra T3 thermal cycler.

The amplification products were resolved using vertical denaturing polyacrylamide gel $(6 \%)$ electrophoresis (Biometra MultiLong) in a $1 \times$ TBE buffer at $53{ }^{\circ} \mathrm{C}$ and a voltage of $5 \mathrm{~V} / \mathrm{cm}$ of the gel length. The DNA samples were prepared in a formamide loading buffer $(10 \mathrm{mM} \mathrm{NaOH}, 0.05 \%$ xylenocyanol, $0.05 \%$ bromophenol blue, $20 \mathrm{mM}$ EDTA) at a volume of $2: 1$, denatured at $95^{\circ} \mathrm{C}$ for $5 \mathrm{~min}$, and $10 \mu \mathrm{L}$ of the mixture was loaded on the gel. The pBR322/BsuRI DNA marker (Fermentas) was used for fragment sizing. Microsatellites were visualized by silver staining using the Beidlers procedure with modifications of Creste et al. (2001). The length of DNA fragments was determined against the size marker using the BIO-1D++ program (Vilber Lourmat).

\subsection{Data analysis}

For each ecological form and each locus, genetic polymorphism was measured as the mean number of alleles $(\mathrm{Na})$. The expected Hardy-Weinberg heterozygosity $\left(\mathrm{H}_{\mathrm{E}}\right)$, as well as the effective number of alleles $(\mathrm{Ne})$, were calculated using the GenAlEx 6.0 program (Peakall and Smouse, 2006). We focused on $\mathrm{H}_{\mathrm{E}}$ to measure heterozygosity because, according to Nei and Kumar (2000), it is considered the best estimator of the genetic variability present in a population. In order to characterize the within-population differences in variability of the examined ecological forms, the genetic distance between pairs of specimens belonging to a given form in each population was calculated using GenAlEx 6.0 software. Based on the obtained values of genetic distance, a variance analysis (ANOVA) was conducted using the Statistica 7.0 program (Statsoft Inc.).

The genetic differentiation across subpopulations was estimated by calculating fixation indices based on an infinite allele model (Kimura and Crow, 1964) and a stepwise mutation model (Kimura and Ohta, 1978). For the infinite allele model Weir and Cockerham's $F_{\text {ST }}$ (Weir and Cockerham, 1984) was used, and for the stepwise mutation model the Slatkin's $R_{\mathrm{ST}}$ (Slatkin, 1995) values were calculated using GenAlEx 6.0. These coefficients are commonly used to estimate genetic structure in natural populations. Obtaining reliable biological information with the use of two estimators depends on a number of factors, and their usability should be evaluated depending on the specific research situation. The use of $F_{\mathrm{ST}}$ may lead to an underestimation of genetic variability, whereas $R_{\mathrm{ST}}$ often turns out to be a more uniform source of biological information although it is accompanied by greater variability (Balloux and Lugon-Moulin, 2002; Slatkin, 1995).

The Analysis of Molecular Variance (AMOVA) method (Excoffier et al., 1992) was used to determine the hierarchical partitioning of total genetic variation of beech on different within-species levels. The
Table I. Characterization of five microsatellite loci of beech (Fagus sylvatica L.) in Poland.

\begin{tabular}{lcccccc}
\hline Locus & $\begin{array}{c}\text { No. of } \\
\text { alleles }\end{array}$ & $\begin{array}{c}\text { Allele size } \\
\text { range (bp) }\end{array}$ & Ne & $\mathrm{H}_{\mathrm{E}}$ & $F_{\mathrm{ST}}$ & $R_{\mathrm{ST}}$ \\
\hline FS1-15 & 14 & $131-211$ & 6.856 & 0.854 & $0,104^{* * *}$ & 0,314 \\
FS1-25 & 16 & $100-184$ & 8.556 & 0.883 & $0,052^{* * *}$ & 0,068 \\
FS1-03 & 19 & $111-211$ & 6.942 & 0.851 & $0,116^{* * *}$ & 0,134 \\
FS1-11 & 15 & $147-201$ & 7.849 & 0.870 & $0,084^{* * *}$ & 0,025 \\
FS4-46 & 17 & $316-427$ & 7.026 & 0.857 & $0,175^{* * *}$ & 0,444 \\
\hline
\end{tabular}

$\mathrm{Ne}$ : Effective number of alleles; $\mathrm{H}_{\mathrm{E}}$ : expected heterozygosity; $F_{\mathrm{ST}}$ and $R_{\mathrm{ST}}$ : measurements of the genetic differentiation over subpopulations. *** $P<0.001$.

first analysis was conducted taking into account the division of the dataset into three populations from different geographic locations. The entire dataset division into three phenological forms was used in the second analysis. Additional analysis was applied to evaluate among- and within-population variance components in every phenological form of beech. The AMOVA procedure was carried out in $\mathrm{Ge}$ neAlex 6.0 using microsatellite distance matrix input for calculation of $R_{\mathrm{ST}}$ and 1000 permutations.

To represent geometric relationships among beech form genotypes, Principal Component Analysis (PCA) was applied in GenAlEx 6.0 using the genetic distances between individuals belonging to respective phenological forms. Scatter diagrams were examined to visualize geometric relationships between individuals of different forms.

\section{RESULTS}

In total, eighty-one alleles obtained at the five highly polymorphic beech microsatellites were studied. The average number of alleles per locus amounted to 16.2 and for individual loci (microsatellites), between 14 (FS1-15) and 19 (FS1-03) alleles were obtained. There was also high differentiation in allele size range (Table I).

Phenological forms of beech showed a high level of intrapopulation variability. The number of alleles was the highest for the early form and the intermediate form (for all loci: 69 and 70, on average: 13.8 and 14.4 , respectively) and the lowest for the late form, amounting to 65 over all loci and 13.0 on average. In general, no statistically significant differences were found between phenological beech forms with respect to the average number of alleles $(\mathrm{Na})$, the effective number of alleles $(\mathrm{Ne})$ and the expected heterozygosity $\left(\mathrm{H}_{\mathrm{E}}\right)$ (Tab. II).

Using $F_{\mathrm{ST}}$ and $R_{\mathrm{ST}}$ indices, genetic variability was examined among populations and phenological forms. The average values of the indices of pairwise genetic differentiation for early, intermediate and late beech forms within the three populations examined yielded $F_{\text {ST }}$ values of $0.135,0.110$ and 0.108 , and $R_{\mathrm{ST}}$ values of $0.365,0.231$ and 0.098 , respectively. All values were statistically significant for both parameters at $P<0.001$ (Tab. II). $F_{\mathrm{ST}}$ and $R_{\mathrm{ST}}$ values indicate that the greatest differences occur among groups of earliest developing individuals from the three populations examined, whereas the smallest differentiation occurs among subpopulations of the late phenological form. 
Table II. Genetic variability of phenological forms of beech (Fagus sylvatica L.) in Poland analyzed at five microsatellite loci. Genetic parameters calculated as a mean for phenological forms from three populations.

\begin{tabular}{lcccccc}
\hline Form & $\begin{array}{c}\mathrm{Na} \\
\text { total }\end{array}$ & $\begin{array}{c}\mathrm{Na} \\
\text { mean }\end{array}$ & $\begin{array}{c}\mathrm{Ne} \\
\text { mean }\end{array}$ & $\mathrm{H}_{\mathrm{E}}$ & $F_{\mathrm{ST}}$ & $R_{\mathrm{ST}}$ \\
\hline Early & 69 & 13.8 & 7.505 & 0.865 & $0,135^{* * *}$ & $0.365^{* * *}$ \\
Intermediate & 70 & 14.4 & 7.007 & 0.855 & $0,110^{* * *}$ & $0.231^{* * *}$ \\
Late & 65 & 13,0 & 7.832 & 0.869 & $0,108^{* * *}$ & $0.098^{* *}$ \\
\hline
\end{tabular}

Ne: Effective number of alleles; $\mathrm{H}_{\mathrm{E}}$ : expected heterozygosity; $F_{\mathrm{ST}}$ and $R_{\mathrm{ST}}$ : measurements of genetic differentiation over subpopulations. $* * P<$ $0.01, * * * P<0.001$.

Table III. Analysis of Molecular Variance (AMOVA) for European beech (Fagus sylvatica L.) based on five microsatellite loci. All values are $P<0.001$.

A. Geographic division (population level)

\begin{tabular}{lccccc}
\hline Source of variation & df & MS & Est. var. & $\%$ & Value \\
\hline Among populations & 2 & 55114.75 & 294.38 & 12 & \\
Within populations & 573 & 2125.49 & 2125.49 & 88 & 0.121653 \\
\hline
\end{tabular}

B. Phenological division (phenological form level)

\begin{tabular}{lccccc}
\hline Source of variation & $\mathrm{df}$ & MS & Est. var. & $\%$ & Value \\
\hline $\begin{array}{l}\text { Among phenological } \\
\text { forms }\end{array}$ & 2 & 25542.81 & 129.54 & 6 & \\
$\begin{array}{l}\text { Within phenological } \\
\text { forms }\end{array}$ & 537 & 2225.06 & 2225.06 & 94 & 0.055017 \\
\hline
\end{tabular}

Based on AMOVA analysis, the impact of two different sources of variation in the genetic architecture of European beech was compared. In these analyses a $6 \%$ genetic variation among phenological forms (Tab. IIIA) and a $12 \%$ genetic variation among populations (Tab. IIIB) was found.

AMOVA performed on subsets of individuals representing particular phenological forms revealed clear differences in the genetic structure between these forms. The share of the among-population variance component was the highest in the early phenological form. The differences among groups of trees representing a given form from different geographic origins gradually decreased in the intermediate and late phenological forms. Within-population variability in individuals representing the form which starts its vegetation early constituted $65 \%$ of the general variability of this form, whereas in the case of specimens belonging to the late form, the withinpopulation component constituted almost $90 \%$ of its overall variability (Tab. IV).

Similar tendencies in the genetic variability of phenological forms were noticed with respect to mean genetic distances among individuals within a given phenological form. The mean genetic distance between pairs of specimens of the early form was similar to that in the intermediate form (11.78 and 11.85 , respectively), whereas the mean genetic distance among specimens of the late form was higher (12.22) and significantly different with respect to values for both the early
Table IV. Genetic structure of phenological forms of beech (Fagus sylvatica $\mathrm{L}$.), based on five microsatellite loci. All values are $P<$ 0.01 .

\begin{tabular}{lcccc}
\hline $\begin{array}{l}\text { Source of } \\
\text { variation }\end{array}$ & Parameter & $\begin{array}{c}\text { Early } \\
\text { form }\end{array}$ & $\begin{array}{c}\text { Intermediate } \\
\text { form }\end{array}$ & $\begin{array}{c}\text { Late } \\
\text { form }\end{array}$ \\
\hline Among populations & Est. var. & 1075.701 & 524.872 & 201.563 \\
& $\%$ of total var. & $36 \%$ & $23 \%$ & $10 \%$ \\
\hline Within populations & Est. var. & 1873.857 & 1748.385 & 1844.392 \\
& $\%$ of total var. & $64 \%$ & $77 \%$ & $90 \%$ \\
\hline
\end{tabular}

form and the intermediate form $(P<0.001)$. In consequence, groups of early-developing individuals differing by geographic origin created separate groups in the PCA, while differences between late forms were less pronounced (Fig. 1).

It is important to emphasize that the presented trends in phenological forms were clearly visible in the genetic structure, although less explicit in the case of indices resulting from allele number. Similar alleles are found in each of the three phenological forms, but in each of these forms the frequency of these alleles differs. Taken together these two facts show that there is a common gene pool for the species, but that it is expressed in different genetic structures in each of the ecotypes.

\section{DISCUSSION}

We present the first attempt at describing and characterizing the genetic structure and the variability of phenological forms of common beech in regard to differences in the date of the beginning of vegetation.

\subsection{Microsatellite variability}

The microsatellites used in our analysis turned out to be highly polymorphic with respect to the number of alleles, which was congruent with other studies. The number of alleles obtained in individual microsatellite loci depended primarily on the number of trees taken into account, but not on the geographic location of populations analyzed. In experiments conducted in northern Spain a similar number of alleles was obtained to the number in our study from a comparable number of individuals (Jump and Peñuelas, 2007). Slightly smaller numbers of alleles in analogous loci were registered in an Italian population where seventy individuals were examined, even though this population was geographically closer to the Spanish sites. Differences in the number of obtained alleles were primarily at loci FS1-15, FS1-11 and FS4-46 (Pastorelli et al., 2003). The higher number of alleles obtained in our study was also accompanied by greater range in their length in comparison with the results of Pastorelli et al. (2003).

\subsection{Allelic pattern across phenological forms}

A comparison of early, intermediate and late beech forms with respect to number of alleles and heterozygosity showed 


\section{Early form}

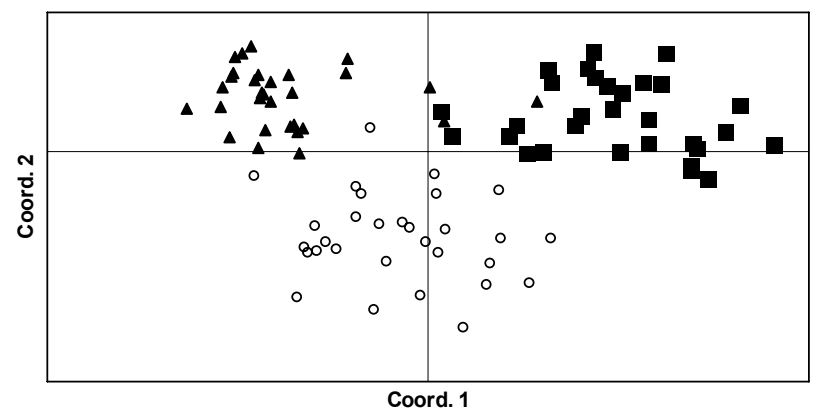

Intermediate form

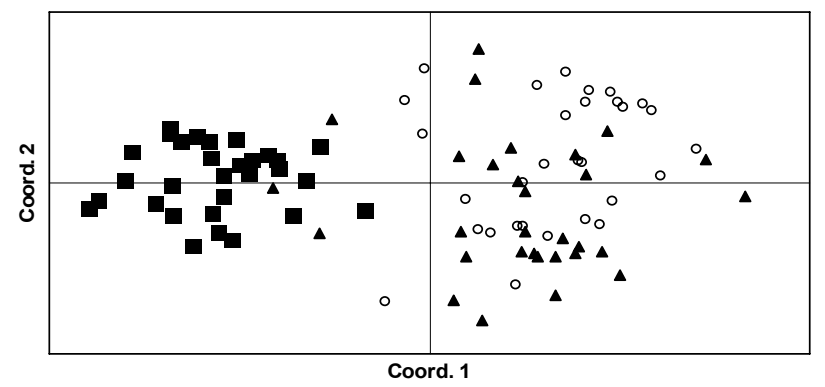

Late form

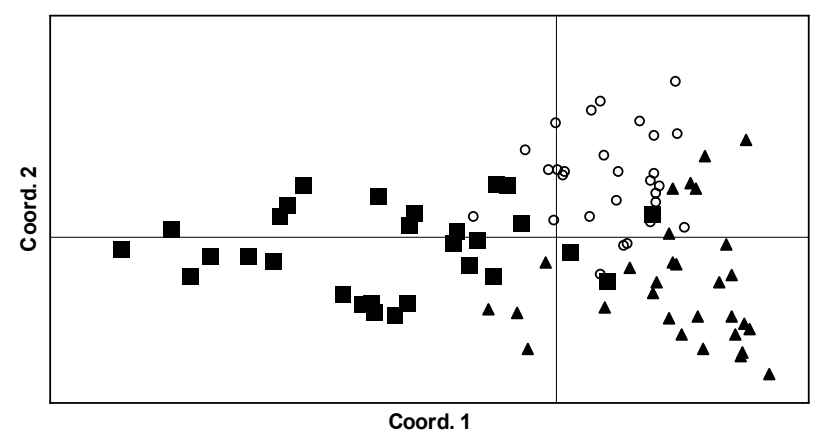

Figure 1. Principal Component Analysis (PCA) for phenological forms of European beech via a matrix of genetic distance between individuals belonging to different subpopulations (forms). Projection into $1^{\text {st }}$ and $2^{\text {nd }}$ coordinates. Percentage of variation explained by the first two axes: $30.22 \%$ and $47.64 \%$ (early form), $31.06 \%$ and $48.94 \%$ (intermediate form), $23.43 \%$ and $45.21 \%$ (late form). Markers: o: in-

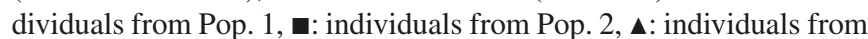
Pop. 3.

that these indices did not differentiate the examined forms in a uniform manner. No clear correlation was found between phenological forms of beech and the number of alleles. Despite the fact that more alleles were found in the early and the intermediate forms (both "total" and "per locus") in comparison with the late form, these differences were not statistically significant.

Values of expected heterozygosity, characterizing genetic variability of beech on the intra-population level, obtained by microsatellite markers in this research, are comparable with re- sults of experiments conducted in Italy (Pastorelli et al., 2003) and Spain (Jump and Peñuelas, 2007). Gomory et al. (2003) also obtained high values of $\mathrm{H}_{\mathrm{E}}$ with the use of isoenzyme markers which indicate that the entire beech genome, both in coding and non-coding regions, retains a very high level of polymorphism inside its population; this feature serves as an evolutionary strategy that allows the retention of the high phenotype flexibility and adaptation skills characteristic of this species. Moreover, the fact that among beech forms with varying dates for the beginning of vegetation the highest intrapopulation genetic variability is shown by the late form suggests that it has special adaptation skills which are conditioned genetically.

\subsection{Genetic structure of phenological forms}

The $F_{\mathrm{ST}}$ and $R_{\mathrm{ST}}$ coefficients indicated significant differences in the genetic differentiation among phenological forms. The $R_{\mathrm{ST}}$ values had a larger degree of variability in comparison with $F_{\mathrm{ST}}$, both for phenological forms and for particular microsatellite loci, but the values were highly statistically significant in the case of both indices. According to the suggestions of Hartle and Clarke (1997), the obtained $F_{\text {ST }}$ values within the range 0.108 (for the late form) to 0.135 (for the early form) show that all phenological forms of beech are marked by moderate population differentiation and within-population variability. The $R_{\mathrm{ST}}$ coefficient, ranging from 0.098 (for the late form) to 0.365 (for the early form), suggests their greater variability.

The Analysis of Molecular Variance (AMOVA) relying on $R_{\mathrm{ST}}$ demonstrated that the genetic variability of groups consisting of specific phenological forms is greater if the form is later. The increase in within-population variability was accompanied by a simultaneous drop in variability among identical phenotypes with various geographic locations.

The variability of the beginning of vegetation both on the population and individual levels, which is observed in the European beech, is a compromise between maximum use of the growth resources and lack of damage by the late frosts. The genetic differences between phenological forms of beech indicated in our investigations suggest that the existence of early and late phenological forms of beech is an evolutionaryshaped strategy for growing in the temperate region. The clear trend in the genetic structure of phenological forms of beech can also suggest the significant influence of the environmental selective factors in shaping of genetic structure and differentiation between phenological forms of beech. Spring frosts play a significant role as a selective factor in native woody species, including beech (Kramer, 1994; Linkosalo et al., 2006). The most vulnerable are seedlings and young trees, because in contrast to the parent trees, their leaves are situated at lower stand layers near the soil surface and thus exposed to higher risk of freezing. The pressure of spring frosts is different in various phenological forms. The frosts are relatively more dangerous for those individuals that develop earliest, since in spring they show greater decline in frost hardiness than the late-developing individuals (Dolnicki and Kraj, 2001). It has 
also been shown that in spring the differences in frost hardiness among phenological forms increase. In general, the risk of damage or elimination of trees by frost is lower if the delay of the beginning of vegetation is greater (Dittmar et al., 2006).

Differences in genetic variability of early-, intermediateand late-developing forms of beech probably have two different sources. The first of them is evolutionary adaptation during the phylogenetic history of the species, and the second is environmental pressure exerted on beech forms in different stands. Both sources influence phenotypic selection, which for its part causes the adaptive evolution within natural populations. Physiological and morphological traits of beech forms show continuous variation. These traits have QTL characteristics and are conditioned not only by genetic properties of organisms but also by increased environmental variance (Riesberg et al., 2002; Kingsolver and Pfennig, 2007). Also, Nielsen and Jørgensen (2003) showed that the genetic variation in physiological variables depends strongly on the environment. Beech forms that develop late have a greater chance of survival in unfavorable temperature conditions and also have a higher level of intra-population genetic variability. Lower genetic variability on an individual level was detected within earlier-developing forms which live under stronger environmental pressure.

Microsatellite loci belong to neutral markers and are not directly linked with adaptive genetic variation (Holderegger et al. 2006). In consequence, the genetic differences between phenological forms of beech indicated in our research do not have a direct effect on the fitness of these forms. However, in some cases there was a strong correlation between neutral and adaptive genetic variation. Some neutral loci are associated with quantitative trait loci (QTLs) and have been used for the preparation of linkage maps of tree species (Scalfi et al., 2004). It is interesting and noteworthy that the time of the start of vegetation for beech forms, an adaptive feature, correlates with the genetic variability of non-coding regions of the genome.

The late beech form occurs mainly in areas with greater frequency of late spring frosts (the north-western part of the geographic range and higher mountainous locations). The forestry service has preferred the late beech form in areas particularly threatened by frosts. Currently, the majority of selection programs are oriented towards specimens and provenances characterized by the late development of buds in springtime (Chmura and Rozkowski, 2002). These are also selective forces that modify the genetic structure of beech species.

The comparison of the genetic structure of phenological forms and the genetic structure of populations shows that within-species differentiation of beech is shaped mostly by geographic locations of beech populations, while the impact of phenological features in this case is much smaller. Irrespective of the criterion of genetic structuring, a key part of the genetic differentiation of beech is retained in individual trees. The European beech is characterized by very high withinpopulation genetic polymorphism, efficient anemophily, common self-sterility and the wide, rather continuous geographic range of the species (Paule, 1995; Wang, 2003). These features contribute to the high phenotypic plasticity of beech trees that allows them to survive many negative environmental conditions, and to a high level of genetic diversity within a tree population rather than among populations (Sander et al., 2000; Sander et al., 2001).

In conclusion, it is believed that forest trees which possess the above-mentioned features are among the most genetically varied organisms (Leonardi and Menozzi, 1996; Merzeau et al., 1994; Wang and Szmidt, 2001), which is shown by the results we obtained.

\section{REFERENCES}

Balloux F. and Lugon-Moulin N., 2002. The estimation of population differentiation with microsatellite markers. Mol. Ecol. 11: 155-165.

Carlson J.E., Tulsieram L.K., Glaubitz J.C., Luk V.W.K., Kauffeldt C., and Rutledge R., 1991. Segregation of random amplified DNA markers in F1 progeny of conifers. Theor. Appl. Genet. 83: 194-200.

Chmura D.J. and Rozkowski R., 2002. Variability of beech provenances in spring and autumn phenology. Silvae Genet. 51: 123-127.

Creste S., Tulmann-Neto A., and Figueira A., 2001. Detection of single sequence repeat polymorphisms in denaturing polyacrylamide sequencing gels by silver staining. Plant Mol. Biol. Rep. 19: 299306.

Dittmar C., Zech W., and Elling W., 2003. Growth variation of common beech (Fagus svlvatica L.) under different climatic and environmental conditions in Europe - a dendroecological study. For. Ecol. Manage. 173: 63-78.

Dittmar C., Fricke W., and Elling W., 2006. Impact of late frost evens on radial growth of common beech (Fagus svlvatica L.) in Southern Germany. Eur. J. Forest Res. 125: 249-259.

Dolnicki A. and Kraj W., 2001. Leaf morphology and the dynamics of frost-hardiness of shoots in two phenological forms of European beech (Fagus sylvatica 1.) from Southern Poland, EJPAU 4(2).

Excoffier L., Smouse P.E., and Quattro J.M., 1992. Analysis of molecular variance inferred from metric distances among DNA haplotypes: application to human mitochondrial DNA restriction data. Genetics 131: 479-491.

Fang J. and Lechowicz M., 2006. Climatic limits for the present distribution of beech (Fagus L.) species in the world. J. Biogeogr. 33: 18041819.

Frewen B.E., Chen T.H.H, Howe G.T., Davis J., Rohde A., Boerjan W., and Bradshaw H.D. Jr., 2000. Quantitative trait loci and candidate gene mapping of bud set and bud flush in Populus. Genetics 154: 837-845.

Gomory D., Paule L., Shvadchak I.M., Popescu F., Sukowska M., Hynek V., and Longauer R., 2003. Spatial patterns of the genetic differentiation in European beech (Fagus sylvatica L.) at allozyme loci in the Carpathians and the adjacent regions. Silvae Genet. 52: 78-83.

Hartl D.L. and Clark A.G., 1997. Principles of population genetics. 3rd Ed. Sunderland (MA), Sinauer Associates.

Hedrick P.W., 2000. Genetics of populations. Jones and Bartlet, Boston, $553 \mathrm{p}$.

Holderegger R., Kamm U., and Gugerli F., 2006. Adaptive vs. neutral genetic diversity: implications for landscape genetics. Landscape Ecol. 21: 797-807.

Howe G.T., Aitken S.N., Neale D.B., Jermstad K.D., Wheeler N.C., and Chen T.H.H., 2003. From genotype to phenotype: unraveling the complexities of cold adaptation in forest trees. Can. J. Bot. 81: 12471266.

Joshi J., Schmid B., Caldeira M.C., Dimitrakopoulos P.G., Good J., Harris R., Hector A., Huss-Danell K., Jumpponen A., Minns A., Mulder C.P.H., Pereira J.S., Prinz A., Scherer-Lorenzen M., Siamantziouras 
A.S.D., Terry A.C., Troumbis A.Y., and Lawton J.H., 2001. Local adaptation enhances performance of common plant species. Ecol. Letters, 4: 536-544.

Jump A.S. and Peñuelas J., 2007. Extensive spatial genetic structure revealed by AFLP but not SSR molecular markers in the windpollinated tree, Fagus sylvatica. Mol. Ecol. 16: 925-936.

Khristov K.P. and Botev N.I., 1981. Effect of late spring frost damage on the increment of beech. Gorskostopanska. Nauka 18: 19-27.

Kimura M. and Crow J.F., 1964. The number of alleles that can be maintained in a finite population. Genetics 49: 725-738.

Kimura M. and Ohta T., 1978. Stepwise mutation model and distribution of allelic frequencies in a finite population. Proc. Nat. Acad. Sci. USA 75: $2868-2872$.

Kingsolver J.G. and Pfennig D.W., 2007. Patterns and Power of Phenotypic Selection in Nature. BioScience 57: 561-572.

Kramer K., 1994. A modeling analysis of the effect of climatic warming on the probability on spring frost damage to tree species in the Netherlands and Germany. Plant, Cel and Environment 17: 367-377.

Leonardi S. and Menozzi P., 1996. Spatial structure of genetic variability in natural stands of Fagus sylvatica L. (beech) in Italy. Heredity 77: 359-368.

Levins R., 1969. Dormancy as an adaptive strategy. In: Woolhouse H. (Ed.), Dormancy and survival. Cambridge University Press, pp. $1-10$.

Linkosalo T., Häkkinen R., and Hänninen H., 2006. Models of the spring phenology of boreal temperate trees; is there something missing? Tree Physiology 26: 1165-1172.

Merzeau D., Comps B., Thiebaut B., Cuguen J., and Letouzey J., 1994. Genetic structure of natural stands of Fagus sylvatica L. (beech). Heredity 72: 269-277.

Nei M. and Kumar S., 2000. Molecular evolution and phylogenetics, Oxford University Press, New York, NY, 333 p.

Nielsen C.N. and Jørgensen F.V., 2003. Phenology and diameter increment in seedlings of European beech (Fagus sylvatica L.) as affected by different soil water contents: variation between and within provenances. For. Ecol. Manag. 174: 233-249.

Ningre F. and Colin F., 2007. Frost damage on the terminal shoot as a risk factor of fork incidence on common beech (Fagus sylvatica L.). Ann. For. Sci. 64: 79-86.

Pastorelli R., Smulders M.J.M., Van't Westende W.P.C., Vosman B., Giannini R., Vettori C., and Vendramin G.G., 2003. Characterization of microsatellite markers in Fagus sylvatica L. and Fagus orientalis Lipsky. Mol. Ecol. Notes 3: 76-78.
Paule L., 1995. Gene conservation in European beech (Fagus sylvatica L.). For. Genet. 2: 161-170.

Peakall R. and Smouse P.E., 2006. GENALEX 6: genetic analysis in Excel. Population genetic software for teaching and research. Mol. Ecol. Notes 6: 288-295.

Rambousek J., 1994. Budbreak phenology of European beech on provenance plots. Zpravy Lesnickeho Vyzkumu. 39: 7-10.

Riesberg L.H., Widmer A., Arntz A.M., and Burke J.M., 2002. Directional selection is the promery cause of phenotypic diversification. PNAS 99: 12242-12245.

Sander T., Konig S., Rothe G.M., Janssen A., and Weisgerber H., 2000. Genetic variation of European beech (Fagus sylvatica L.) along an altitudinal transect at mount Vogelsberg in Hesse, Germany. Mol. Ecol. 9: 1349-1361.

Sander T., Rothe G.M., Weisgerber H., and Janssen A., 2001 Allelic and genotypic variation of 13 European beech (Fagus sylvatica L.) - populations in Hesse, Germany. For. Genet. 8: 13-24.

Scalfi M., Troggio M., Piovani P., Leonardi S., Magnaschi G., Verdrmin G.G., and Menozzi P.A., 2004. RAPD, AFLP and SSR linkage map, and QTL analysis in European beech (Fagus sylvatica L.). Theor. Appl. Genet. 108: 433-441.

Schieber B., 2006. Spring phenology of European beech (Fagus sylvatica L.) in a submountain beech stand with different stocking in 19952004. J. For. Sci. 52: 208-216.

Slatkin M., 1995. A measure of population subdivision based on microsatellite allele frequencies. Genetics 139: 457-462.

Teissier du Cross E., Le Tacon F., Nepveu G., Pardé J., and Timbal J., 1981. Le hêtre. Département des Recherches Forestières, INRA, Paris, $613 \mathrm{p}$.

Vernier M., Teissier du Cross E., Du-Cros E.T., and Cross E.D., 1996. Genetic variation of beech. Implications for reforestation in Picardy and Normandy. Rev. For. Fr. 48: 7-20.

Visnjic V.C. and Dohrenbusch A., 2004. Frost resistance and phenology of European beech provenances (Fagus sylvatica L.). Allg. Forst. Jagdztg. 175: 101-108.

Wang K.S., 2003. Genetic diversity and temporal genetic structure in European beech (Fagus sylvatica L.). Silvae Genet. 52: 100-106.

Wang X.-R. and Szmidt A.E., 2001. Molecular markers in population genetics of forest trees. Scand. J. For. Res. 16: 199-220.

Weir B.S. and Cockerham C.C., 1984. Estimating F-statistics for the analysis of population structure. Evolution 38: 1358-1370. 